\title{
The Monuments of Wooden Architecture of Shenkurskiy Uyezd of the XIX Century: From the Tradition to the Architecture Style
}

\author{
Olga Zinina, ${ }^{1, *}$
}

\begin{abstract}
${ }^{1}$ Scientific Research Institute of the Theory and History of Architecture and Urban Planning, Branch of the Central Institute for Research and Design of the Ministry of Construction and Housing and Communal Services of the Russian Federation, Moscow, Russia

*Corresponding author. E-mail: olg-zinina@yandex.ru
\end{abstract}

\begin{abstract}
The article is devoted to the XIX century wooden church monuments of Shenkurskiy uyezd of Arkhangelsk province that have not been studied before. The method of work is based on the study of archival historical sources, conducting field surveys, historical and architectural analysis of forms, as well as attracting analogs. The purpose of the research is to identify the uniqueness of monuments' architectural and structural design features by comparing them with their analogs and considering them in the context of the wooden architecture of the region. The identified architectural features of researched churches and chapels correspond to the character of the distribution of traditions of wooden architecture of the Povazhye region. A stylistic and typological assessment of the objects under study is given.
\end{abstract}

Keywords: Monuments of wooden architecture, wooden churches, Povazhye region, Shenkurskiy uyezd, model projects

\section{INTRODUCTION}

The monuments of Russian wooden architecture of the XIX century are the least studied layer in the history of Russian architecture. The structure of the buildings of this period does not fit into the traditional understanding of the monuments of wooden architecture. Nevertheless, these objects deserve special attention, as they are not studied at all and have not been even noticed by previous researchers in the XX century. For example, A.V. Opolovnikov recorded and measured the buildings of the XVII-XVIII centuries and did not pay attention to the later buildings located in the neighborhood. Many of them are now irretrievably lost, and we do not have a complete idea of what these buildings looked like. This attitude towards the later monuments of architecture in Soviet times is related to the prevailing interest in earlier objects as well as tendencies to return to their original appearance [1]. Therefore, it is not surprising that the buildings of the period under consideration were left out. Nowadays, we see growing interest in wooden church architecture of the XIX century. New researches

*Fund: This paper was funded by the Program of Fundamental Researches of the Ministry of Construction, Housing and Utilities of the Russian Federation and the Russian Academy of Architecture and Construction Sciences 2020, the Research Project 1.2.5. by E.V. Khodakovsky, in which special attention is given to the history and architecture of particular objects, are devoted to this topic [2], [3], [4]. The topic of the decorative treatment of the facades of churches of the XIX century was studied by A. B. Bode [5].

This article deals with previously unresearched late wooden churches located on the territory of Shenkurskiy uyezd. The research is aimed at obtaining new knowledge about the wooden architecture of the XIX century and a more comprehensive understanding of the connection between the traditional design features and the new style. The method of work is based on the study of archival historical sources, conducting field research works, historical and architectural analysis of forms, as well as attracting analogs.

\section{HISTORICAL AND ARCHIVAL DATA AND THE CURRENT SITUATION}

Shenkurskiy uyezd has existed until 1929 and was the southernmost in the Arkhangelsk province. In the North, it was bordered by Kholmogorsk and Pinezhskiy uyezds. In the east, it was bordered by Solvychegodskiy uyezd of Vologda province. From the South, it was bordered with Velskiy uyezd of Vologda province, from the West it was bordered with Kargopolskiy uyezd 
of Olonets province and Onezhskiy uyezd of Arkhangelsk province. Numerous parishes were located on the banks of the Vaga and Northern Dvina rivers. The region of Povazhye has got its name from the name of one of them.

According to documents, in 1895 it was the most populated district of the entire Arkhangelsk province. By January 1, 1895, there have been 57 church parishes in the uyezd: "There are 101 parish churches, 17 ascribed churches, 2 house churches, and 120 in total, not counting the churches of the Shenkurskiy nunnery and the hermitage belonging to it. Of these, 30 are stone-built, 88 are wooden, and two are located inside wooden houses" [6]. At that time, there have been 72 chapels throughout the uyezd.

Before the revolution, more than a hundred wooden churches have been preserved in Shenkurskiy uyezd. More than half of them (about 60) were the buildings of the XIX - early XX centuries. Nowadays, about 20 churches have survived. The uyezd included two modern districts - Shenkurskiy and Vinogradovsky. Until 1917, about 60 wooden churches have been located on the territory of the contemporary Shenkurskiy uyezd, including 35 objects of the XIX early XX centuries. Nowadays, only 13 churches and chapels have been preserved in the following settlements: Aleshkovskaya, Boltinskaya, Korbala, Medlesha, Nyunezhskaya, Osinovskaya, Ostakhino, Rykalovskaya, Sarayevskaya, Smetanino, Bogoslovskoye, Himanevo, Chasovenskaya. It is quite probable that in Smetanino and Aleshkovskaya, the churches used log structures of the XVIII century, but transported and completely rebuilt. Particular attention should be paid to Demidovskaya church in Nizhnyaya Puya which is an earlier church rebuilt at the end of the XIX century. On the territory of the Vinogradivsky district, there are late churches preserved in the villages of Verhnyaya Vaenga, Gorodok, Nizhnyaya Vaenga, Tulgas, Chamovo, Shidrovo.

\section{TRADITIONAL TECHNIQUES AND FORMS ON THE MONUMENTS OF THE XIX CENTURY}

The XIX century was a transitional period in Russian wooden architecture characterized by the movement from the tradition to the architectural style. The proportions, shapes, and the scale of structures have changed. In contrast to the monuments of wooden architecture of the XVI-XVIII centuries, in which the structure of the building was demonstrated and determined its appearance, the structural composition of the buildings of the XIX century recedes to the background. At that time, builders no longer attached importance to the external beauty of $\log$ walls and corner joints, they no longer built such magnificent churches as before, most of the volume of which has not been justified functionally in any way. The utilitarian approach became a priority. Roofs of buildings started to be increasingly covered with iron, as a more reliable and durable material. Traditional carved wooden parts have lost their direct functional purpose and remained only as decorative elements. In the XIX century, timber became, above all, an inexpensive and easily accessible construction material.

At first glance, it may seem that all traditions have been forgotten, and we are dealing with a completely different architecture. But it is premature to judge only by the appearance of buildings, so it is necessary to pay attention to the internal and structural composition of churches. It is essential to consider the nearest analogs on the example of earlier buildings. After such an analysis, it becomes evident that there is still a lot of traditional elements in the new style of architecture. The architecture of the time we are considering is a mix of traditional wooden architecture design principles with the novel stylistic features.

Let's consider specific traditional techniques that have been present at this time in the investigated territory.

The walls of chapels and churches, in most cases, as before, remained made of log. The frame was only used in the structures of completions. The most common corner joint was the connection without residue. Boulders continued to be used as a foundation, as before.

The shapes of church completions, despite the change in proportions, remain the same. The tented roof on the church of the XIX century in the Uksora village is not as high and majestic as on the buildings of Shenkurskiy uyezd of the XVII-XVIII centuries (Church of the Annunciation built in 1677 in the Bereznik village, Trinity Church of 1707 in the Rostovkoye village, Ascension church of 1752 in the Koncegorye, St. Nicholas Church of 1752 in the Shastki village), nevertheless, tented roofs continue to be used steadily, though in a modified and simplified form.

The onion-shaped dome or puchina is traditional to the churches of the Povazhye region [7]. The Transfiguration Chapel of 1894 in Chasovenskaya village is a vivid example of how strong the tradition was ("Fig. 1"). Such a form was especially widespread at the end of the XVIII century in the investigated territory: the church of John the Baptist (1780-1781) in the Litvinovo village, the church of Vlasiy (1795) in the Tulgas village, the church of Paraskeva (1797) in the village of Korbala. The earliest monument of the Povazhye region with a similar type of completion is the church of John Chrysostom 1733 in the village of Bereznitskoye. 


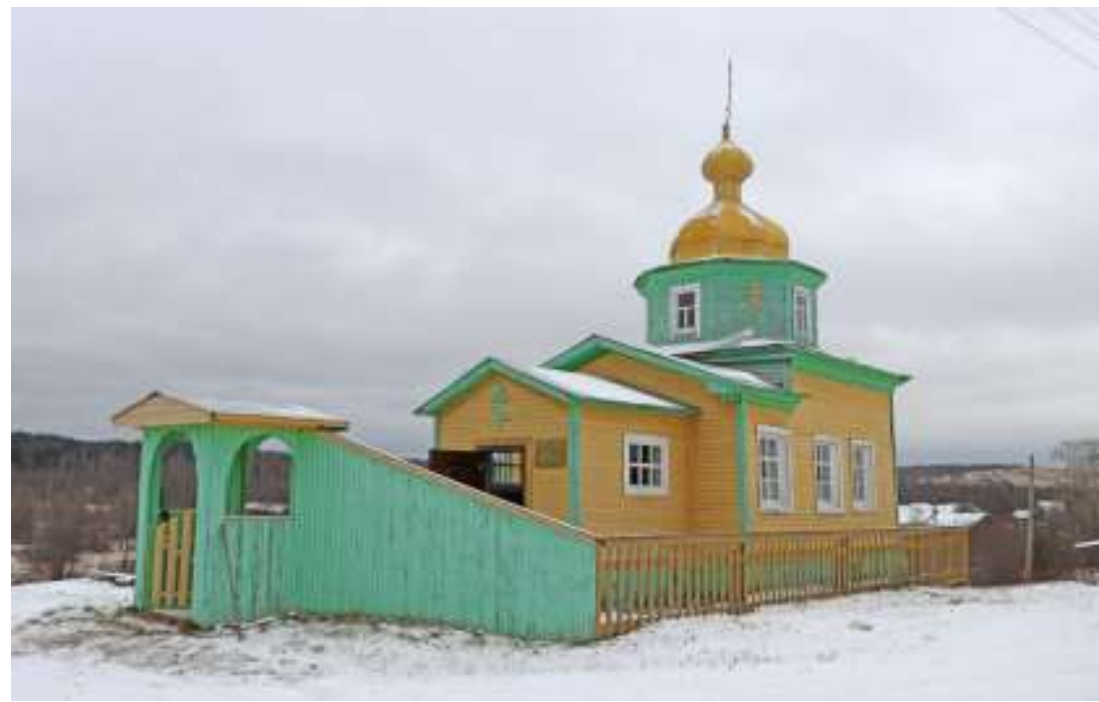

Fig. 1. The Chapel of the Transfiguration in Chasovenskaya village, 1894.

Besides the shape of the roof completion, it is necessary to note the general composition of the main $\log$ structure in the form of an octagon on the cube, which has remained unchanged in the XIX century. Only the proportions of volumes changed in relation to each other.

Nikolskaya chapel of 1850 in the Gorodok village is an example of an archaic building. A simple in plan chapel under a gable roof. This building is likely based a. The photo by the author, 2019 . on an earlier log structure, which was rebuilt in the XIX century, by adding a narthex.

The Varlaam Vazhsky chapel built in 1894 is a close-to-square $\log$ house with a four-pitched roof, surmounted by an octagon with false windows and a dome ("Fig. 2"). Despite the later ornamental decoration, behind the ceiling of the chapel, we find an utterly traditional structure - a log frame of the cube, supporting the upper octagon.

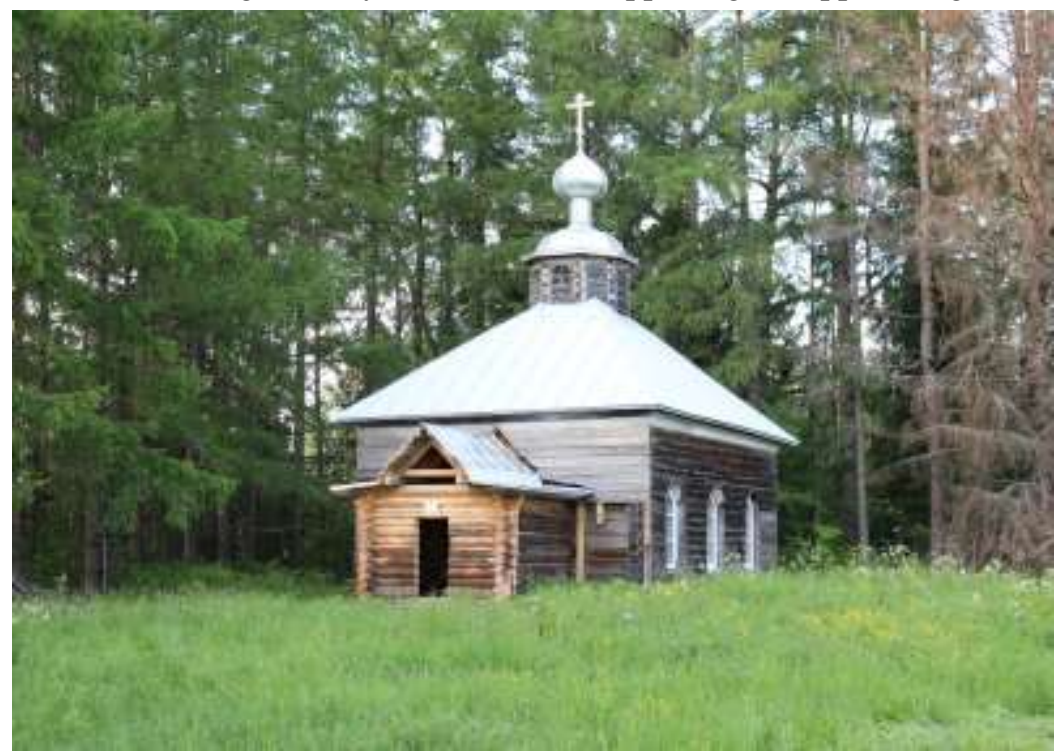

Fig. 2. The Chapel of Varlaam Vazhvskiy of the St. John the Theologian Varlaamiev Vazhvskiy Monastery, 1894.

The Church of Elijah, the Prophet in Nunezhskaya village in 1901, has double floors ("Fig. 3"). The rough floor is made of poles. Such a solution is found in traditional heated log houses. Its purpose is not clear here, as the building has never been heated. 


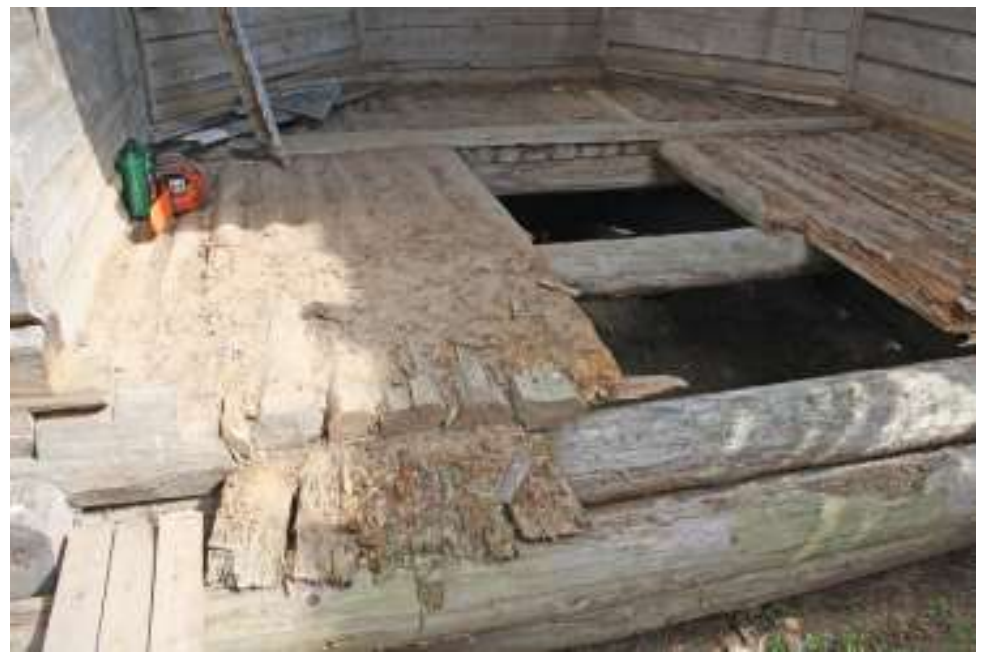

Fig. 3. Rough floors in the Church of Elijah the Prophet in Nyunezhskaya village, 1901.

Despite the many archaic features in the structures, we find a completely different approach to the construction of churches. A utilitarian and simplified approach to the entire construction process is becoming dominant. The quality of timber decreases and the skill of wood processing with a hand tool degrades. The iron-coated domes have a more simplified structure than the traditional ones, coated with wooden shingles. Wooden crosses on the domes are often replaced with more durable forged ones. Door and window frames get thinner, and the openings become larger. The structural rigidity of the log frame is supported by vertical compresses installed in partitions between windows. On the inner side, the walls, as a rule, are cut in a right angle and covered with plaster or canvas upholstery. On the outer side, the walls are being increasingly covered.
The photo by the author, 2015 . The plinth is often being rusticated. The desire to imitate stone buildings is very characteristic of this time. Thus, wooden monuments lose their inherent aesthetics and individuality.

Examples include the largest preserved churches of the XIX century of the Shenkurskiy uyezd.

The St. Nicholas Church of 1802 in the village of Aleshkovskaya, is the earliest building under consideration (Fig. 4). The initial construction of the completion is not known for sure. The church is similar to its earlier predecessor - the Church of the Nativity of Christ in 1769 in the village of Bolkachevskaya (UstPuya). Under the roof slopes, the cornice with decorative elements in the shape of superimposed horizontal rhombuses has been preserved.

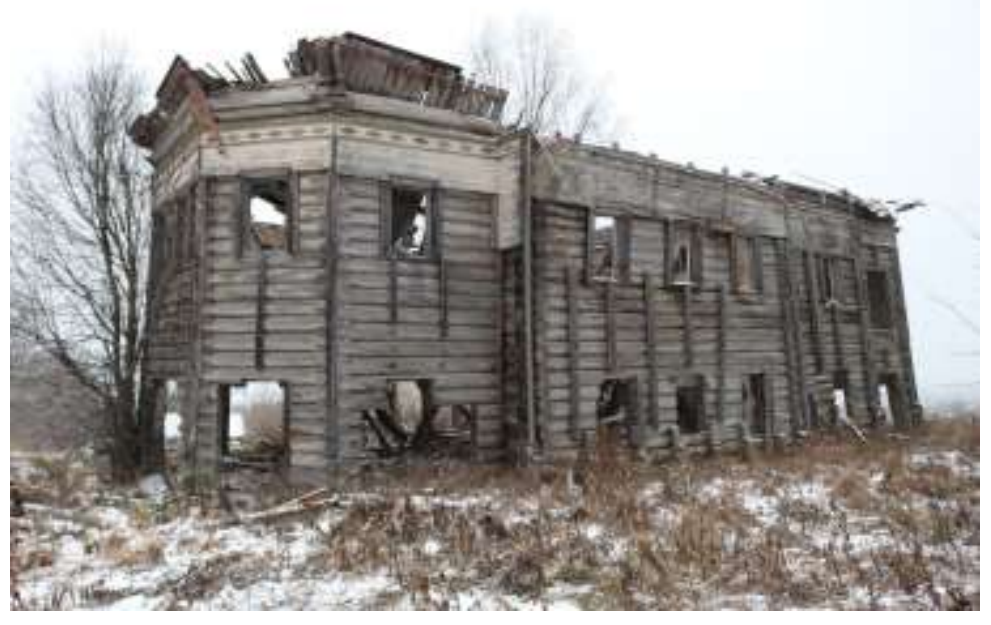

Fig. 4. The Church of St. Nicholas the Wonderworker in the village of Aleshkovskaya, 1802. 
The Church of St. Vladimir has been built in 1795 in the Demidovskoe village (Lower Puya) and was reconstructed in 1882. Probably at the same time, it was reinforced with vertical walls due to its height and large cut through windows and covered with painted canvas ("Fig. 5").
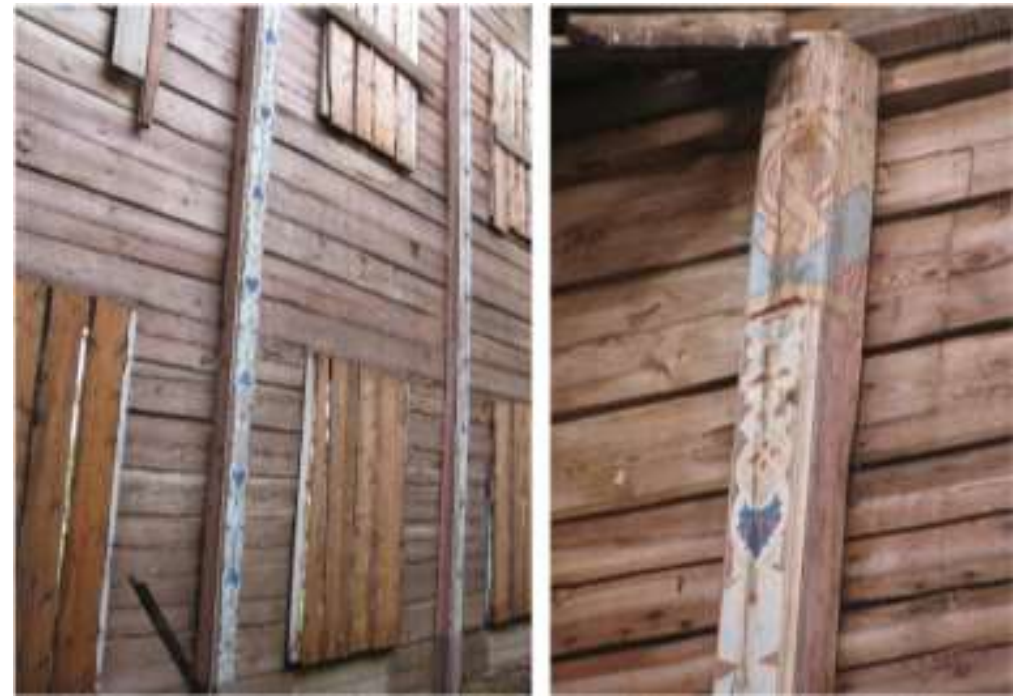

Fig. 5. Vertical compresses in the interior of the Church of the Vladimirskaya Icon of the Mother of God, 1795 (1882) in the village of Demidovskoye (Nizhnyaya Puya).

The Church of Clement of 1880 in the village of Tulgas is a building with a symmetrical-axial composition of the plan and modest decoration. It can be attributed to classicism, which was reworked and came to the Russian North with a significant delay.

\section{MODEL PROJECTS}

In the XIX century, the practice of using "model projects" became widespread. They have been published as a collection of several albums. One of them is the "Atlas of Plans and Facades of Churches, Iconostases to Them and Chapels Approved for Church Construction in Villages", Edition of the Holy Synod, 1911. There was also an earlier edition of 1899. [8] Model projects have been developed for both wooden and stone churches. The provincial architects used the drawings from these albums to develop their own designs. The similarity of the majority of church buildings in the second half of the XIX century is mainly due to the fact that the number of commissions was large, and the ability of provincial architects to design was limited. Therefore, the architect presented to the communities a ready-made project, only slightly modifying it. There were usually several projects of churches of various sizes available.

There were not many model projects built exactly like they have been published in the Arkhangelsk Province album, but there were many examples of reconstructions according to the adapted projects. There were about a dozen projects that have been used several
The photo by I.S. Rybin, 2018 times with small variations for the construction of churches throughout the entire territory of the Arkhangelsk province. They were compiled by adapting and reworking model projects from albums. A characteristic feature of the implementation of such projects was almost complete lack of decoration. Apparently, it was quite expensive, thus not every parish could afford it.

At the end of the XIX century, this Atlas included the projects by Ivan Ivanovich Sviyazev, a senior, permanent member of the Commission for Technical and Construction Affairs of the Department of Agriculture of The Ministry of State Property. These projects were sent out to the dioceses in order to facilitate the design of churches for parishes. In 18571859 , I.I. Sviyazev has made several basic projects of wooden churches: for 150 people, for 250-300 people, for 450-500 people. Each of them was designed in several versions, with differences in details, the shape of the dome, as well as other features.

These projects have been used as models. They were not reproduced verbatim on the spot and were changed as necessary. In addition, the traditions of local carpenters affected the construction process, as they used the techniques and features that they have been familiar with.

The Church of Elijah the Prophet built in 1901 in the Nunezhskaya village and the Church of Dmitry Solunsky constructed in 1904 in the village of Korbala is a revised project №30 - "the church for 150 
parishioners". In the original project by I.I. Sviyazev there has been a one-domed cube with framed windows on the northern and southern facades, with a pentahedral altar and a rectangular vestibule, with a fairly rich decor. In the variant adapted for the Arkhangelsk province we see the same quadruple, but with almost no decorative elements, but with a bell ringer attached from the west, which has not been present in the original project.
Two more objects can also be attributed to the same project № 30. This is the intercession Church of 1902 in the village of Rykalovskaya. Here we see a budget and a very simplified version of the project under consideration. Only the four-pitched roof over the small prayer room and the built window reveals the connection with the previous design. The Chapel of the Descent of the Holy Spirit built at the end of the XIX century in the village of Osinovskaya also has similar features with project № 30 (Fig. 6).

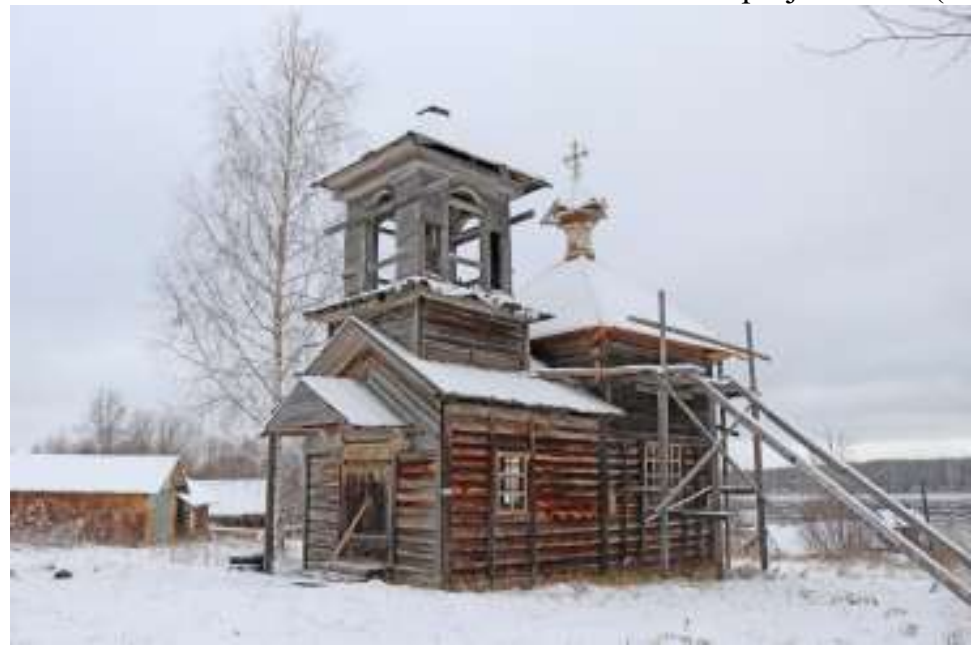

Fig. 6. The Chapel of the Descent of the Holy Spirit the end of the XIX century in the village of Osinovskaya.

In contrast to project № 30, all four of these objects have a belfry above the narthex. It should be noted that the belfry with a spire has become a favorite feature of the wooden monuments of the Shenkurskiy uyezd in the XIX century. For example, on the St. George's chapel built in 1732, after the reconstruction of 1843 , a postframe belfry appears on four pillars above the porch ${ }^{1}$.

The Church of Lazarus of 1898 in the village of Medlesha is a revised project № 23 "church for 450-500 parishioners" ("Fig. 7"). In The original project by I.I. Sviyazev, the main volume, is designed in the shape of an equilateral octagon, with rectangular side narthexes, an altar, and a refectory. In the built version, we see the same composition, but with a simplified completion, no decoration, and a bell tower attached to the West of the main volume of the building. A very similar project was implemented in Arkhangelsk during the construction of the Peter and Paul Church of 1895 in Maimaks.

1748. P. 4 .
State Archive of Archangelsk Oblast. F. 29. Inv. 31. D.

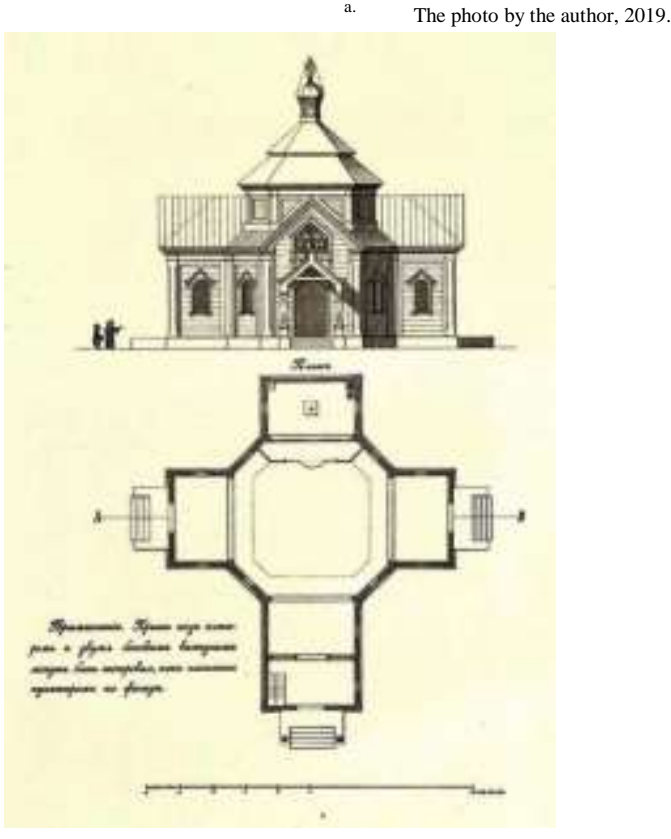

Fig. 7. The model project № 23 "Church for 450 - 500 parishioners". Plan, western facade.

In the Church of the Purification of the Lord in 1895 in the village of Gorodok and the Church of Florus and Laurus built in 1887 in the village of Himanevo, we see 
all sorts of characteristic elements from model projects, such as diamond-shaped windows of the second tier of the two-story cube, which we notice on the project № 21 - "the church for 250 parishioners. On the St. Nicholas Church in 1891 in the village of Boltinskaya, diamond-shaped windows remained as decorative frames. We don't see any verbatim reproduction of the model project № 21 in Shenkurskiy uyezd.

The Church of St. Nicholas the Wonderworker of 1849 in the village of Ostakhino was built, apparently, according to an adapted model project.

This is evidenced by the actual exact copy of this church, which was located on the bank of the Tarnia River in the Uksora village.

\section{CONCLUSION}

In the XIX century, there have been over a hundred churches in Shenkurskiy uyezd, most of which were wooden. More than half of them were built at the same time. At that time, the district was one of the most populated and rich in the Arkhangelsk province.

The considered wooden churches reveal the features of their architectural and artistic development. We see a delay in the spread of architectural styles, a mixture of traditional techniques and forms with new stylistic influences. At this time, model projects have been widely used. They were implemented in different ways, depending on the capabilities of the parish and the skills of local craftsmen. Even within this approach, there was a certain individuality and traditionality present.

By today, about twenty churches of the XIX century have survived from the former variety. The condition of most of them is an emergency. The design of late constructions does not imply such a reserve of strength as earlier monuments. Therefore, they are doomed to disappear in the nearest future. And this is despite the fact that the buildings considered have a unique historical and cultural value and deserve the most careful attention and preservation. Thus, wooden churches and chapels of the XIX-early XX centuries represent a significant, least studied, and most vulnerable layer in the history of Russian wooden architecture.

\section{References}

[1] Bode, "Methods of the Restoration of Wooden Architectural Monuments in Russia," Proc. 2019 Int. Conf. of Architecture: Heritage, Traditions and Innovations (AHTI 2019), vol. 324, pp. 357-361.

[2] E. Khodakovsky, Wooden Church Architecture of the Russian North, Regional Schools and Traditions (XIV- XIX centuries). London, New York: Routledge, 2016.

[3] O. Zinina, A. Noskova, E. Khodakovsky, "Wooden Church Architecture of Kargopol in the Second Third of the XIX
Century: The Hodegetria Church in Malaya Shalga and St. Georgiy Church in Zamoshye (Derevyannoe Hramovoe Zodchestvo Kargopolya Vtoroy Treti XIX Veka: Odigitrievskaya Cerkov V Maloi Shalge I Georgievskaya Cerkov V Zamoshye)," Architectural Heritage, issue 70. Saint Petersburg, Moscow: Kolo, 2019, pp. 116-133 [in Russian].

[4] E. Khodakovsky, A. Ermakova, E. Frolova, "St. Nicholas Church in Lovzang - a Monument of Wooden Architecture of Kargopol of the End of the XIX Century (Nikolskaya Cerkov V Lovzange - Pamyatnik Derevyannogo Zodchestva Kargopolya Konca XIX Veka)," Architectural Heritage, issue No. 71. Saint Petersburg, Moscow: Kolo, 2019, pp. 79-88 [in Russian].

[5] A. Bode, "The Painting Of The Facades Of The Wooden Churches Of The XIX - Early XX Centuries (Pokraska Fasadov Derevyannyh Cerkvey XIX - Nachala XX Vekov)," Proc. 2019 Conf. Ryabininskie Chteniya. Petrozavodsk, 2019, pp. 216-218 [in Russian].

[6] A Brief Historical Description of The Parishes and Churches of the Archangelskaya Diocese. Issue 2. Uyezds: Shenkurskiy, Pinezhskiy, Mezenskiy and Pechorskiy (Kratkoe Istoricheskoe Opisanie Prihodov I Cerkvej Arhangelskoj Eparhii. Vypusk II. Uezdy: Shenkurskiy, Pinezhskiy, Mezenskiy I Pechorskiy. Arhangelsk). Arhangelsk, 1895, pp. 5-6 [in Russian].

[7] A. Bode, "Onion-Shaped Single-Headed Completions as One of the Characteristic Features of the Wooden Churches of the Povazhye and Severodvinsk River Area (Lukoviceobraznye Odnoglavye Zaversheniya Kak Odna Iz Harakternyh Osobennostej Derevyannyh Cerkvej Povazhya I Severodvinskogo Porechya)," Architectural Heritage, issue 61. Saint Petersburg, Moscow: Kolo, 2015. pp. 70-84 [in Russian].

[8] The Atlas of Plans and Facades of Churches, Iconostases to Them and Chapels Approved for Church Construction in Villages (Atlas Planov I Fasadov Cerkvej, Ikonostasov K Nim I Chasoven, Odobrennyh Dlya Rukovodstva Pri Cerkovnyh Postrojkah V Seleniyah). Moscow: Publication of the Holy Synod (Izdaniye Svyateyshego Sinoda), 1899. pp. 1-50 [in Russian]. 